\title{
PENGENALAN TOKOH DAN KARYA SASTRA PERANCIS BAGI SISWA PEMBELAJAR BAHASA PERANCIS DI SMAN 1 PURWAKARTA
}

\author{
Ferli Hasanah, Mega Subekti, Vincentia Tri Handayani \\ Fakultas Ilmu Budaya, Universitas Padjadjaran Jl. Raya Bandung-Sumedang KM 21, Jatinagor \\ E-mail: ferli.hasanah@unpad.ac.id
}

\begin{abstract}
ABSTRAK. Kegiatan yang dilaksanakan pada bulan oktober 2018 ini mengakomodasi kebutuhan siswa-siswa SMAN 1 Purwakarta yang mempelajari bahasa Perancis untuk dapat mengenal tokoh dan karya sastra Perancis. Kegiatan Pengabdian Pada Masyarakat ini sesuai dengan alur riset penelitian yang membahas karya sastra frankofon. Dengan dilaksanakannya kegiatan ini diharapkan para pembelajar pemula bahasa Perancis dapat memperoleh pengetahuan yang lebih luas mengenai karya sastra frankofon sehingga tumbuh motivasi yang kuat untuk melanjutkan belajar Bahasa Perancis ke tingkat yang lebih tinggi. Dengan metode belajar mengajar, kegiatan telah berhasil dilaksanakan. Hasil yang diperoleh dari kegiatan ini adalah tumbuhnya minat siswa terhadap literatur Frankofon khususnya karya-karya klasik. Dari penelusuran minat siswa berdasarkan angket yang telah diberikan, diketahui sebanyak 80\% peserta kegiatan berpendapat bahwa pengetahuan mengenai tokoh dan karya sastra Perancis dan penggunaan teks sastra dalam kegiatan pembelajaran sangat bermanfaat untuk mengasah kompetensi berbahasa.
\end{abstract}

Kata kunci: frankofon; bahasa; pendidikan

ABSTRACT. The activity that held on October 2018, accommodates the needs of SMAN 1 Purwakarta students who learn French to get to know French authors and their work. This activity is in accordance with the research flow that discusses francophone literature. We hope that the French learners in this school can gain a broader knowledge of francophone literary works so that there is a strong motivation to continue learning French to a higher level. The activity has been successfully carried out with the teaching and learning methods. The results obtained from this activity are the growing interest of students in the Francophone literature, especially classical works. From tracking students' interests based on the questionnaire that has been given, it is known that $80 \%$ of the activity participants thought that knowledge of French author, literary works and the use of literary texts in learning activities were very useful for improving language competence.

Key words: francophone; language; education

\section{PENDAHULUAN}

Bahasa merupakan alat penting dalam berkomunikasi. Dengan kemampuan komunikasi yang baik seseorang dapat dengan mudah beradaptasi dengan lingkungannya. Terlebih lagi jika orang tersebut banyak menguasai bahasa asing, ia dapat mengembangkan potensi untuk bisa maju dalam ruang lingkup yang lebih luas di dunia internasional. Kusumah menjelaskan bahwa penguasaan bahasa asing bertujuan untuk meningkatkan sumber daya manusia, menaikkan daya saing bangsa pada tingkat internasional, serta merespon berbagai tantangan (perubahan jaman) (2007: 112).

Saat ini, telah banyak sekolah di Indonesia yang mengharuskan siswa-siswanya mempelajari bahasa asing sebagai mata pelajaran pilihan guna menunjang dan menambah kompetensi kebahasaan. Salah satu bahasa yang diajarkan adalah Bahasa Perancis. Bahasa Perancis dikenal sebagai bahasa yang romantis atau bahasa cinta (Dominguez, 2018: 3). Meskipun demikian, banyak yang menganggap belajar bahasa Perancis itu sulit. Hal ini dapat dipahami mengingat banyaknya perbedaan mendasar antara bahasa ibu, misalnya bahasa Indonesia atau bahasa daerah, dengan bahasa yang dipelajari. Dengan demikian perlu adanya strategi khusus dari pengajar bahasa Perancis untuk membangkitkan semangat dan motivasi para pembelajar, salah satunya dengan menggunakan teks sastra sebagai media pembelajaran.

Dianggap sebagai sarana komunikasi terbaik, karya sastra tampaknya dapat menjadi perangkat pedagogis terbaik di kelas Français Langue Etranger (Bahasa Perancis Untuk Bahasa Asing). Penggunaan karya sastra bertujuan untuk membantu pembelajar mendapatkan bahasa yang lebih baik. Menurut Peytard (1986: 583), teks sastra bekerja secara non-linear dan non-univocal, tanpa diatur oleh berbagai pendekatan.Teks itu mengungkapkan dan mengilustrasikan berbagai potensi bahasa. Sementara itu, menurut Moody dalam The teaching of Literature (1971), salah satu tujuan sastra diajarkan di sekolah adalah untuk memupuk keterampilan berbahasa. Dengan demikian, teks sastra justru bisa digunakan sebagai alat untuk memupuk keterampilan berbahasa, dalam hal ini adalah keterampilan pembelajar berbahasa Perancis.

Todorov seperti dikutip Albert dan Souchon (2000:11) menjelaskan bahwa kesusastraan berada di tengah-tengah masyarakat untuk mendidik seseorang dalam arti sempit maupun mendidik masyarakat dalam arti yang luas serta memberi kesenangan bagi pembacanya. Pemikiran itu sesuai dengan apa yang dikatakan Schmitt Viala yakni karya sastra merupakan bagian dari kehidupan masyarakat karena dapat mendidik manusia dan menghibur manusia (1982 : 17). Selain terdapat nilai-nilai estetis, dalam sastra terdapat pula nilai-nilai kehidupan manusia yang dapat dianut oleh manusia.

Sastra sendiri bisa dipahami sebagai karya imajinatif yang menggunakan medium bahasa dan mempunyai fungsi estetis dominan (Wellek \& Warren, 1993:14). Sedang Sumarjo (1986:3) mendefinisikan bahwa sastra adalah ungkapan pribadi manusia yang berupa pengalaman, pemikiran, perasaan, ide, semangat, keyakinan dalam 
suatu gambaran konkrit yang membangkitkan pesona dengan alat bahasa. Hudson (1963: 11) juga berpendapat bahwa sastra adalah catatan penting tentang apa yang dilihat manusia dalam kehidupan; apa yang telah mereka alami, apa yang mereka pikirkan dan rasakan tentang aspek-aspek itu yang menimbulkan minat paling cepat dan abadi bagi semuanya. Berdasarkan beberapa pendapat itu, dapat disimpulkan bahwa bahasa mempunyai peran penting dalam sastra dan dapat dikatakan bahwa bahasa tidak dapat dipisahkan dengan sastra.

Di dalam kelas bahasa, kesusasteraan diberikan kepada siswa bukan untuk dijadikan suatu pengetahuan khusus, atau pelengkap suatu program pengajaran bahasa, namun kesusasteraan dijadikan bahan ajar untuk belajar bahasa, sejarah, masyarakat dan budaya (Alber, Souchon, 2000:51). Dengan belajar bahasa Perancis menggunakan teks-teks sastra, pembelajar akan lebih mengenal kebudayaan Perancis. Sebagaimana telah diketahui saat seseorang mempelajari bahasa asing, secara langsung ataupun tidak langsung ia akan bersinggungan dengan budaya dari bahasa yang dipelajari. Tidak mungkin rasanya jika mempelajari bahasa asing tanpa mengetahui sedikitpun budayanya. Dalam lingkup kesusastraan dunia, sastra Perancis menempati posisi yang sangat penting. Banyak pengarang maupun filsuf Perancis yang begitu terkenal di seluruh dunia sehingga menjadi rujukan di bidangnya, seperti: Jean-Paul Sartre, Albert Camus, Simone de Beauvoir dengan berbagai esai filosofisnya, maupun Victor Hugo atau Marcel Proust dengan banyak novelnya.

Dengan mengetahui bahwa sastra Perancis memiliki pesonanya tersendiri, maka diharapkan pembelajar dapat tertarik untuk mencari dan membaca berbagai karya tersebut sehingga dapat menunjang pembelajaran di kelasnya. Sementara itu dalam pembelajaran bahasa, pada umumnya terdapat empat kompetensi yang dipelajari, yaitu kemampuan menyimak dokumen suara (Compréhension Orale), membaca (Compréhension écrite), produksi lisan (Production orale) dan produksi tulisan (Production écrite). Adapun kegiatan pembelajaran kesusastraan di dalam kelas bahasa ditujukan untuk meningkatakan keterampilan berbahasa, dapat dilakukan dengan cara memberi kegiatan berupa Memahami wacana (Comprendre), Menganalisa (Analyse) dan Menulis (Ecrire) (Exel dan Ravier, 2008:10).

SMAN 1 Purwakarta di Jawa Barat adalah salah satu sekolah yang mengajarkan Bahasa Perancis secara berkesinambungan setiap semesternya. Pada umumnya, teks sastra jarang digunakan dalam kegiatan belajar di SMA, karena seringkali dianggap sebagai teks yang sulit dipahami dan tidak cocok untuk pembelajar SMA yang tergolong pada pembelajar pemula. Padahal sebaliknya, teks sastra justru mempunyai potensi untuk mengembangkan pembelajaran yang lebih hidup, bahkan untuk kelas pemula, tidak selalu harus melihat sudah berapa lama seseorang belajar bahasa Perancis.
Dengan latar belakang tersebut, kegiatan Pengabdian ini bertujuan untuk mengenalkan karya dan tokoh sastra Perancis sebagai motivasi dan sarana bagi siswa pembelajar bahasa Perancis untuk meningkatkan kompetensi berbahasa. Dengan membaca dokumen/ literatur dalam bahasa yang dipelajari, para pembelajar pemula akan menemukan banyak hal baru yang mungkin saja tidak dipelajari di dalam kelas, seperti istilah, idiom, kosa kata, juga tata bahasa tertentu. Dengan menemukan hal-hal yang baru dalam karya sastra yang dibaca akan timbul rasa ingin tahu dari pembelajar sehingga dapat memiliki motivasi untuk belajar lebih giat lagi.

Sebagai pengajar bahasa Perancis, tim pelaksana Pengabdian Pada Masyarakat menyadari bahwa pihak Perguruan Tinggi, seperti Universitas Padjadjaran, perlu mengambil langkah-langkah strategis untuk ikut mengenalkan serta mengembangkan metode belajar yang efektif bagi para pembelajar pemula bahasa Perancis. Dengan terjun langsung ke masyarakat sasaran yang sesuai dengan latar belakang pendidikan tim peneliti, diharapkan munculnya semangat yang lebih besar dalam belajar dan rasa percaya diri dalam mempelajari bahasa Perancis. Untuk itu, tim pelaksana Pengabdian Pada Masyarakat melaksanakan kegiatan bertema "Pengenalan Karya Sastra Perancis Bagi Siswa Pembelajar Bahasa Perancis di SMAN 1 Purwakarta." Kelompok sasaran kegiatan secara spesifik adalah murid-murid SMA Negeri 1 Purwakarta yang merupakan pembelajar pemula bahasa Perancis. Adapun materi yang mereka pelajari meliputi tokoh dan karya sastra Perancis yang terkenal dan mendunia.

\section{METODE}

Tahapan yang dilalui dalam kegiatan pengabdian masyarakat ini meliputi tiga tahapan, yaitu persiapan, tahap pelaksanaan, serta tahap evaluasi. Pada tahap persiapan tim menentukan sekolah yang menjadi sasaran kegiatan. Setelah berkoordinasi dengan sekolah yang dituju, selanjutnya tim melakukan survey ke lokasi kegiatan, yaitu SMAN 1 Purwakarta untuk mendapatkan gambaran yang objektif dan faktual dari publik sekaligus mitra kegiatan ini. Kemudian telah dilakukan perencanaan kegiatan, yang meliputi jenis dan jadwal kegiatan, pemilihan dan penentuan media dan materi setiap kegiatan, serta penanggung jawab dan pelaksana setiap kegiatan.

Pada tahap pelaksanaan kegiatan terdiri dari menyampaikan materi melalui metode pengajaran dalam bentuk ceramah dan tanya jawab. Meteri dipaparkan dengan menggunakan power point sedangkan tanya jawab dilakukan secara interaktif dengan memanfaatkan aplikasi Sli.do yang memungkinkan adanya diskusi interaktif antara siswa dan pemateri. Setelah materi selesai disampaikan, tim membagikan angket pada para siswa untuk mengevaluasi keberhasilan kegiatan yang dilakukan.

Tahap terakhir yaitu tahapan evaluasi, tahap ini dilaksanakan dengan mengadakan rapat bersama anggota 
tim. Pada kesempatan ini dilakukan pengumpulan data untuk pembuatan laporan kegiatan serta menyimpulkan hasil angket untuk mengetahui sejauh mana keberhasilan kegiatan yang telah dicapai.

\section{HASIL DAN PEMBAHASAN}

Pelaksanaan kegiatan berlangsung pada tanggal 15 Oktober 2018 dengan memanfaatkan jam mata pelajaran bahasa Perancis. Siswa yang menjadi peserta kegiatan adalah kelas 12 IPA 8 dan IPA 9. Materi yang relevan dengan mata pelajaran pada hari tersebut membuat koordinasi dengan pihak sekolah menjadi lebih mudah. Para siswa yang merupakan pembelajar bahasa Perancis, memiliki waktu belajar untuk mata pelajaran tersebut di dalam kelas hanya 2 jam pelajaran per minggu dengan seorang guru pengampu. Oleh karena itu, meskipun sudah belajar hampir tiga tahun kemampuan yang dimiliki oleh siswa-siswa tersebut masih dalam tahap débutant (pemula).

Hal ini terlihat dengan banyaknya pertanyaanpertanyaan tata bahasa dasar yang dituliskan melalui aplikasi Sli.do.Aplikasi inidigunakanuntukmenghidupkan suasana pembelajaran, pemberian materi dilakukan secara interaktif dengan memanfaatkan aplikasi Sli.do yang memungkinkan adanya diskusi interaktif antara siswa dan pemateri. Aplikasi ini dapat dibuka secara daring melalui website di smartphone masing-masing siswa. Siswa yang ingin mengajukan pertanyaan dapat langsung menuliskannya lewat aplikasi ini secara anonim. Dengan anonimitas ini, siswa dapat dengan leluasa mengajukan pertanyaan yang berkaitan maupun yang tidak berkaitan dengan materi tanpa merasa canggung atau malu.

Berdasarkan aplikasi tersebut dapat diketahui sebanyak 18 orang di kelas 12 IPA dan 15 orang dari kelas 9 mengajukan pertanyaan yang berkaitan dengan bahasa Perancis. Dengan demikian dapat dikatakan kegiatan pengabdian ini mendapatkan tanggapan yang positif dari para peserta. Dari berbagai pertanyaan yang diajukan, satu pertanyaan sama yang diutarakan oleh 10 orang peserta, yaitu mengapa bahasa Perancis itu sulit sekali. Selain itu, berdasarkan angket yang telah disebarkan, rata-rata siswa mengalami kesulitan memahami tata bahasa Perancis terutama dalam membedakan genre (gender) kata benda. Masalah pelafalan (pronounciation) juga menjadi kendala utama karena para siswa tidak terbiasa mendengarkan bahasa penutur asli maupun mendengarkan rekaman/ audio dari situs-situs yang dapat diakses.

Berdasarkan angket yang telah disebarkan, sebagian besar siswa yang menjadi peserta Pengabdian Pada Masyarakat tidak memiliki keinginan untuk melanjutkan kuliah ke jurusan Bahasa Perancis karena telah memiliki pilihan di bidang IPA sebagai jurusan tujuan setelah menyelesaikan studi di SMAN 1 Purwakarta. Sementara itu, dari 68 peserta, terdapat 16 peserta Pengabdian Pada Masyarakat yang ingin melanjutkan belajar Bahasa Perancis ke tingkat yang lebih tinggi karena menganggap
Bahasa Perancis sangat bermanfaat dan mereka memiliki keinginan untuk melanjutkan kuliah di Perancis. Banyaknya pernyataan maupun pertanyaan siswa yang mengeluhkan sulitnya belajar bahasa Perancis juga menunjukkan bahwa perlu adanya upaya yang dilakukan untuk meningkatkan motivasi mereka.

Solusi yang dapat diberikan untuk meningkatkan motivasi belajar siswa adalah dengan menggunakan berbagai sumber pembelajaran yang dapat digunakan dalam proses belajar mengajar di kelas, di antaranya dengan menggunakan teks cerita, lagu, film pendek, maupun video yang dapat diunggah secara gratis dari Youtube. Pembelajaran di kelas juga dapat dilakukan dengan berfokus pada kebutuhan siswa. Misalnya jika ada siswa yang mengalami kesulitan pelafalan, guru dapat mencari materi yang dapat meningkatkan kemampuan siswa. Situs-situs belajar Bahasa Perancis banyak menyediakan materi pembelajaran baik sesuai pokok bahasan maupun sesuai tingkat kemampuan berbahasa yang diinginkan.

Sementara itu, teks sastra seringkali dianggap sulit untuk digunakan menjadi bahan pembelajaran. Meskipun demikian, saat ini karya sastra Perancis, khususnya karya klasik, telah banyak disajikan dengan bahasa français facile, atau Bahasa perancis untuk tingkat dasar. Oleh karena itu, guru bahasa Perancis bisa menggunakan teks tersebut sebagai sarana pembelajaran. Selain melatih kemampuan berbahasa, teks sastra juga berfungsi untuk membuka wawasan mengenai budaya Perancis.

Dengan pemaparan mengenai tokoh dan karya sastra Perancis yang disampaikan dalam bentuk presentasi power point, para peserta kegiatan Pengabdian Pada Masyarakat mengetahui 10 tokoh sastra Perancis yang terkenal, yaitu Molière, Jean de la Fontaine, Victor Hugo, Alexandre Dumas, Emil Zola, Gustave Flaubert, Antoine de Saint-Exupery, Marcel Proust, Jacques Prevert, dan Albert Camus. Selanjutnya karya penting dari masingmasing pengarang juga dijelaskan. Penjelasan setiap tokoh dimulai dengan identitas singkat pengarang, penghargaan yang telah didapatkannya, serta gambar atau ilustrasi sampul depan karyanya sambil menerangkan sedikit ringkasan cerita karya tersebut. Pada saat pemaparan, antusiasme peserta terlihat dari adanya beberapa pertanyaan mengenai cerita, terutama untuk kisah yang baru mereka dengar. Diskusi kemudian berlanjut dengan berbagai pertanyaan dari pemateri mengenai apakah para peserta gemar membaca atau tidak, karya sastra apa yang pernah mereka baca, dan apa saja manfaat mengetahui tokoh dan karya sastra dalam pembelajaran bahasa. Pada umumnya, jawaban yang didapatkan adalah para siswa tidak suka membaca karya sastra karena tidak terbiasa atau pun kurang tertarik, meskipun demikian ada juga yang mengetahui beberapa karya sastra Indonesia yang terkenal dan telah membacanya, khususnya novel-novel remaja. Mengetahui kondisi tersebut pemateri menekankan pentingnya menumbuhkan minat baca untuk menambah pengetahuan. 
Terkait dengan pembelajaran Bahasa Perancis, pema-teri menjelaskan bahwa para siswa juga dapat memanfaatkan berbagai fasilitas yang ada seperti akses internet atau perpustakaan di IFI Bandung untuk mendapatkan buku-buku français facile yang dapat digunakan untuk melatih kompetensi berbahasa serta mengenal budaya dari bahasa yang dipelajari. Dengan mengetahui tokoh dan karya sastra Perancis yang terkenal dari pemaparan pemateri maka para siswa mendapatkan gambaran teks mana yang cocok dan dapat digunakan sebagai sarana pembelajaran. Berdasarkan angket yang telah disebarkan, sebanyak $80 \%$ peserta berpendapat bahwa mengetahui tokoh dan karya sastra Perancis serta menggunakan teks yang sesuai dengan level mereka akan sangat berguna dalam meningkatkan kemampuan berbahasa Perancis.

\section{SIMPULAN}

Pelaksanaan kegiatan Pengabdian Pada Masyarakat ini telah selesai dilakukan. Secara keseluruhan, dari mulai tahap awal persiapan, pelaksanaan dan penyusunan laporan, semua tahapan kegiatan terlaksana dengan baik. Selanjutnya tim dapat terus mengembangkan kerjasama dengan pihak mitra, dalam hal ini SMAN 1 Purwakarta agar dapat melaksanakan kegiatan lain yang memberikan manfaat bagi kedua belah pihak.

Dalam hal pembelajaran, pembelajar pemula membutuhkan motivasi yang besar untuk mempelajari bahasa asing. Selain motivasi, dibutuhkan strategi yang tepat untuk belajar sehingga kegiatan belajar dilaksanakan secara efektif. Strategi belajar efektif ini dimulai dengan memfokuskan proses pembelajaran pada empat kompetensi berbahasa, yaitu menyimak, membaca, berbicara dan menulis. Dengan mengetahui strategi yang dapat diaplikasikan dari masing-masing kompetensi tersebut, pembelajar pemula bisa meningkatkan kemampuan bahasa Perancis secara menyeluruh, tidak hanya dari satu segi saja. Untuk meningkatkan berbagai kompetensi tersebut diperlukan metode yang tepat dan terarah untuk menunjang pembelajaran, salah satunya dengan menggunakan karya sastra sebagai sarana pembelajaran. Untuk itu, pengetahuan mengenai pengarang dan karya sastra Perancis menjadi sangat penting bagi pembelajar pemula.

\section{DAFTAR PUSTAKA}

Albert Marie Claude, Marc Souchon. 2000. Les textes Litteraires en Classe de Langue, Hachette: Paris

Dominguez, Susanti. 2018. Belajar Inti Bahasa Perancis (Apprendre le Français Essentiel). Bandung: Citra Aditya Bakti.

Exel, Marie Hélène Estéoule. 2008. Livres Ouverts. Presses Universitaires de Grenoble (PUG), Grenoble

Hudson, William Henry.1949.An Introduction to the Study of Literature. London: George. G. Harrap \& Co. Ltd.

Kusumah, Ina Yusuf. 2007. Ilmu dan Aplikasi Pendidikan: Pendidikan Bahasa Asing. Bandung : Imperial Bhakti Utama

Moody, H.L.B. 1979. The teaching of Literature. London: Longman.

Peytard, J. 1986, "Didactique, sémiotique, linguistique" Syntagmes 3. Paris, p.247.

Schmit. M.P dan A.Viala. 1982. Savoir Lire. Didier: Paris Gramedia 